\title{
The Impact of Blended Learning Strategies on Improving Jordanian EFL Students' Grammar and Vocabulary
}

\author{
Mohammad Akram Alzu'bi \\ English Department, Ajloun University College, Al-Balqa Applied University, Jordan
}

\begin{abstract}
The main purpose of the study is to measure the effect of blended learning strategy in improving EFL learners' competence in vocabulary and grammar. The sample of the study consists of 50 Jordanian undergraduate students studying English language and Literature at Al Balqa Applied University. The participants were divided equally into two groups: the experimental group learned the target vocabulary and grammar through blended learning strategies and the control group learned the same vocabulary and grammar through the traditional way of teaching. The participants sat for a pre-test and a post-test. Additional to the conventional methods of teaching, the researcher used the e-learning system developed by Al Balqa Applied University to teach grammar and vocabulary to the experimental group. The findings of the study indicated that the experimental group was significantly improved compared to the control group. The study concluded that blended learning strategy was a useful tool to enhance students' learning of English vocabulary and grammar.
\end{abstract}

Keywords: blended learning; competence; EFL; grammar; vocabulary

DOI: $10.7176 / \mathrm{JEP} / 11-23-01$

Publication date:August $31^{\text {st }} 2020$

\section{Introduction}

\subsection{Overview}

Learning vocabulary and grammar is an essential aspect of mastering a foreign language and its four skills (reading, writing, speaking, and listening). Language learners need to know a sufficient amount of the target vocabulary to understand a text or to communicate an idea (Barra 2005). Other linguists claim that learning the vocabulary of the target language is essential to construct complete spoken or written discourse (Nation 2001). Similarly, grammar is critical for learning a second language since it is used to organize words and phrases to create a meaningful sentence (Swan 2008). It is not enough to know the words of the target language, but it is a must to understand how to organize these words to form comprehensible sentences and to comprehend others' sentences. Since learning the vocabulary and grammar of the foreign language is important in learning the language, teachers used different methods and approaches to teach grammar and vocabulary effectively. One of these approaches is the traditional one, in which teachers can only use face-to-face interaction to teach a foreign language. Teachers, as well as students, depend only on written materials like books and papers to gain knowledge. This approach has some advantages since teachers give learners immediate feedback and encourage them and make them more engaged, which are essential for learning.

Another approach to learning and teaching is online learning. In this method, learners learn the content of any course by using technology and internet-based courses offered synchronously or asynchronously. While learners in synchronous learning meet at a pre-determined time, learners in asynchronous learning have access to learning resources at any time (Hrastinski 2008). This method has some advantages, including location flexibility, timeflexibility, cost-effectivity, and self-paced learning. However, this method has some drawbacks since learners will not have the opportunity to get engaged in direct social interaction with their teachers and colleagues (Swan 2002; Olt 2002).

In recent days, there is an interest in combining traditional teaching methods with online instruction to make use of the advantages of both approaches. Combining technology represented in online instruction and face-toface method are called blended learning (Graham 2006; Krasnova 2015). According to Friesen (2012) blended learning involves combining technology (media and internet) with classroom activities that require the co-presence of student and teacher. Besides, Rovai \& Jordan (2004) defined blended learning as a combining traditional methods of teaching (face-to-face method) and online instruction within a particular course.

Scholars recognized different advantages of blended learning for the learners of a foreign or second language. Firstly, students will be more confident and motivated while using the language inside the class since they have the opportunity to practice online with their peers or teachers (Marsh 2012). The fear of using language may be the main obstacle in learning a second or a foreign language. Secondly, using blended learning allows the students to practice language more since they learn the language in class using traditional methods and to continue learning outside the classroom using online methods. Thirdly, blended learning may enhance social interaction in the classroom. Students have more time to interact with their colloquies and teachers and to ask questions, which in turn will motivate them to learn the target language (Walsh 2016). Fourthly, blended learning is the best method of learning a language for part-time students (Procter 2003). Thus, students may take traditional teaching in class 
and e-learning at home. Finally, blended learning may save time since language learners may finish their readings and assignments in a short period (McCarthy \& Murphy 2010).

\subsection{Problem of the study}

Students in the Jordanian universities face a severe problem in learning English as a foreign language. They have limited knowledge of vocabulary and grammar, and those who know these subskills cannot use them appropriately. Thus, new methods should be adopted to enhance learning the vocabulary and grammar of English. Several researchers claimed that blended learning is an effective method in learning vocabulary and grammar in the Jordanian context. It is worth noting that most English classes in Jordanian universities are not equipped with technological devices, so instructors depend on the classical method of teaching. Since 2017, Al Balqa Applied University launched an e-learning system based on e-learning strategies. As a result, the present study aims to investigate the impact of using blending learning on improving components of language (grammar and vocabulary).

\subsection{Research questions:}

The present study aims to answer the following question:

1. What is the impact of blended learning approach on improving Jordanian EFL students' grammar and vocabulary?

\subsection{Limitations of the study}

The study has some limitations. Firstly, the sample of the study is limited to 50 undergraduate students taken from Al-Balqa Applied University. Secondly, the study is limited to nine chapters taken from "English Vocabulary in Use (Advanced)" and nine chapters taken from "Oxford Practice Grammar Advanced". Finally, the study did not take into consideration the influence of gender in learning the vocabulary and grammar of English as a foreign language.

\section{Literature review}

Many studies reported a positive effect of the blending learning approach on learning English and its subskills. For example, Zhang, Song \& Burston (2011) investigated the effect of blending learning represented in using mobile phones on learning vocabulary. The study found out that students learned vocabulary more effectively compared to those who study vocabulary using paper material. Similarly, Khazaei \& Dastjerdi (2011) investigated the effect of SMS as a blended learning method on enhancing EFL learners' vocabulary enhancement. The study found out that students who learn vocabulary by using blended learning method had better results than the control group who learned vocabulary by the traditional method. In another study, Vasbieva et.al (2016) compared between the effect of using blended learning methods and the traditional method on vocabulary learning. The findings of the study showed that blended learning strategy enhances the students' vocabulary achievement positively. Similarly, Pazio (2010) studied the usefulness of email as a blended learning method on teaching English as a foreign language. The study found out that the blended learning method assisted students in expanding vocabulary, get rid of spelling mistakes, and improve writing.

Other studies investigated the impact of using a blended learning approach in teaching and learning grammar. Al-Jarf (2005) conducted a study to explore the influence of blended learning on learning grammar among female students at King Saud University. The study found out that blended learning has a positive effect on students' achievement in grammar. The study also found out that students' attitudes to this new method were positive. In a similar vein, Qindah (2018) examined the influence of blended learning on EFL students' usage of grammar in context. The findings of this study showed a positive effect of blended learning on students' results in grammar. Isti'anah (2017) examined the impact of blended learning on grammar' achievements among Indonesian students at the English Letters Department, Sanata Dharma University. The study found out that blended learning is a beneficial method since it assists students in learning grammar. In another study, Al-Essa (2018) examined the impact of Edmodo as a blended learning method on enhancing Saudi EFL students' grammar and their attitudes towards using Edmodo grammar activities. The study found out that students exposed to blending learning scores higher in the post-test than the control group. Besides, the findings of the study revealed that students had positive attitudes towards using Edmodo grammar activities.

Many studies also traced the impact of blended learning on the proficiency of language skills: reading, writing, listening, and speaking. Adas and Bakir (2013) conducted a study to find out the role of blended learning strategy on the improvement of writing skills among Palestinian students. The findings of the study showed a positive impact of this strategy on learning English writing skills. So \& Lee (2013) examined the influence of blended learning on developing EFL learners' writing skills in higher education. The results of the study showed that the students who used blended learning got higher results for their writing. Zumor, Rafaai, Bader Eddin \& AL-Rahman (2013) also investigated the impact of blended learning on Saudi EFL Students' development of reading skills and vocabulary. The study found out that blended learning has a positive impact on students' reading skills and 
vocabulary. Schechter et al. (2015) studied the effect of blended learning methods to English reading skills. The study found out that the experimental group exposed to blended learning methods get higher marks than the control group.

Many researchers pointed out that blended learning plays a significant role in motivating students to learn English. Sucaromana (2013) and Wang, Chung \& Hattingh (2014) examined the influence of blended learning strategy on student's motivation. These two studies found out that students who learn English using the blended learning strategy are motivated better than those who exposed to traditional teaching methods

In the Jordanian context, a few studies investigated the effectiveness of blended learning in enhancing learning English. Al Bataineh, Banikalef \& Albashtawi (2019) investigated the impact of the blended learning method on grammar among Jordanian EFL learners and the attitudes towards this method. The study found out that the participants exposed to blended learning approach outperform the participants exposed to traditional teaching methods. Bataineh \& Mayyas (2017) explored the effect of Moodle as blended learning method on Jordanian EFL learners' grammar and reading comprehension. The results of the study showed that the results of students exposed to blended learning are higher compared to control exposed traditional teaching methods. Another study by Fakhir (2015) investigated the influence of the blended learning approach on the academic achievement of 50 Jordanian sixth-grade female students. The findings of the study showed that the role of blended learning in learning English grammar and vocabulary was positive.

It is clear from the previous literature that the blended learning approach improves the EFL learners' proficiency in English. It has a positive influence on different language components, and it enhances the whole learning process. Thus, the present study aims to find out the effectiveness of blended learning method on improving Jordanian EFL learners' vocabulary and grammar.

\section{Methods}

\subsection{Sample of the study}

The sample of the study consists of 50 undergraduate students who all of them were enrolled in two classes: Building vocabulary and Grammar in the first semester 2019/2020. These students were second-year students studying English language and literature at Al Balqa Applied University/ Ajloun University College. The study used a control group consisted of 25 students, and the experimental group consisted of 25 students. The students were chosen randomly regardless of social background, class, or gender.

\subsection{Instruments}

The instruments of the study were pre-test and post-test. The pre-test and post-test consisted of four grammar exercises, each exercise included10 items, and four vocabulary exercises, each composed of 10 items. The tests were based on nine units from "English Vocabulary in Use (Advanced Language) and ten units from "Oxford Practice Grammar Advanced".

\subsection{Procedure of the study}

At the beginning of the semester, the experimental and control group sat for a pre-test to make sure that both groups are equivalent. The control group learned the vocabulary and grammar of English using the conventional teaching method. In contrast, the experimental group learned the same grammar and vocabulary using blended learning strategies (face-to-face learning and online instruction). Both groups took nine units in vocabulary class based on the book "English Vocabulary in Use (Advanced)" by McCarthy, M. \& O'Dell, F. 2008. The units covered the following topic: work and study, people and relations, travel, the environment, society and institutions, leisure and lifestyles, health, media, and technology. Both groups also took ten units in grammar class based on "Oxford Practice Grammar Advanced" by G. Yule, including the following topics: sentences, tenses, modals, negatives and questions, the passive, articles, determiners and quantifiers, relative clauses, conditionals, and reporting.

Additional to traditional instruction, the experimental group gets exposed to online learning methods. The researcher used an e-learning system designed by Al Balqa Applied University to create an online group for the experimental group. This system provides many resources, such as adding book, file, folder, page, and URL, and adding many resources, including assignment, chat, web conference, glossary, choice, quiz, lesson, survey, and wiki.

The researcher used videos, PowerPoint sheets, URL links, workshops, glossary, online lessons, quizzes, and assignments to help the experimental group to master the vocabulary and grammar of English. The additional online resources were prepared by the researcher based on the textbooks. Students also encouraged to use the chat icon to ask the researcher questions and comments on their assignment. The researcher welcomed these comments and questions and made immediate feedbacks. Besides, this program allowed students to chat with each other; so, the researcher encouraged them to chat with each other and ask the researcher's questions. It is worth noting that the online group can be accessed by students at any time using their smartphones and laptops.

After 14 weeks, both groups sat for the post-test to evaluate the effect of blended learning and traditional 
learning method on student's achievement. The results were analyzed using an independent $t$-test, and the significance level was set at $0.05(\mathrm{p}<.05)$.

T-test was used to make sure that experimental and control have the same level of proficiency in grammar and vocabulary:

Table 1: results of pre-test of the experimental and the control group

\begin{tabular}{|l|l|l|l|l|l|l|}
\hline & Group & $\mathrm{N}$ & Mean & Std. Deviation & $\mathrm{t}$ & Sig. (2-tailed) \\
\hline \multirow{2}{*}{ Vocabulary } & Control group & 25 & 3.68 & 1.51987 & & \\
\cline { 2 - 8 } & Experimental & 25 & 3.48 & 1.68622 & .441 & .662 \\
\hline \multirow{2}{*}{ Grammar } & Control & 25 & 3.52 & 1.35769 & & \\
\cline { 2 - 8 } & Experimental & 25 & 3.48 & 1.68622 & .092 & .927 \\
\hline
\end{tabular}

The results above showed that there were no differences between the two groups in the pre-test since the $T$ value for grammar and vocabulary was larger than .05 .

\section{Findings and discussion}

An independence sample test was used to figure out if there were significant differences between the control group and the experimental group in the post-test. If the P-value less than .05, the differences were considered significant. Consider the following table:

Table 2: Results of the post-test for the control and experimental group

\begin{tabular}{|l|l|r|r|r|r|r|}
\hline & GROUP & \multicolumn{1}{c|}{$\mathrm{N}$} & \multicolumn{1}{c|}{ Mean } & Std. Deviation & $\mathrm{t}$ & \multicolumn{1}{c|}{ Sig. (2-tailed) } \\
\hline \multirow{2}{*}{ Vocabulary } & Control & 25 & 5.36 & 1.22 & 4.355 & .000 \\
\cline { 2 - 8 } & Experimental & 25 & 7.08 & 1.55 & & \\
\hline \multirow{2}{*}{ Grammar } & Control & 25 & 4.96 & 1.10 & & .000 \\
\cline { 2 - 7 } & Experimental & 25 & 7.36 & 1.29 & 7.092 & \\
\hline
\end{tabular}

The results also revealed that the experimental group showed improvement in using vocabulary better than the control group since the mean of the experimental group (7.08) was larger than the control group (5.36). The results revealed significant differences between the experimental and control group in the post-test in favor of the experimental group at P-value .000 .

Furthermore, the study showed that the experimental group showed improvement in learning grammar better than the control group since the mean of the experimental group (7.36) was larger than the control group (4.96). The results revealed significant differences between the experimental and control group in the post-test in favor of the experimental group at P-value .000 .

The findings of the study showed that blended learning had improved the grammar and vocabulary of Jordanian EFL learners. These results go in line with all previous studies in the literature review, such as Zhang, Song \& Burston (2011); Fakhir (2015); Qindah (2018); Zumor et al. (2013); Al Bataineh, Banikalef \& Albashtawi (2019). Furthermore, the researcher noticed that many students involved in blended learning used exceptional and useful vocabulary in interactions with their teachers. Also, many students used complex and sophisticated structures in class and out-class activities. Additional benefits of blended learning that are not part of the study that many students who enrolled in blended learning are more excited to practice the language with their colloquies and teachers compared to those who exposed to the traditional method. The researcher noticed that participants in the experimental group feel more comfortable in using English with teachers. Even some of them start using English with their teachers outside class. This is an exciting result that should be discussed further in future research.

The positive results of the current study were expected because of the advantages of blended learning which plays a significant role in increasing the amount of vocabulary and strengthen their grammar. Blended learning gives students enough time after the class to use language. Moreover, using the traditional method of teaching with e-learning proves to be an effective medium for cooperative and self-learning at the same time.

\section{Conclusion}

The present study examined the impact of blending learning approach on improving the vocabulary and grammar of Jordanian EFL students. The study proved that using blended learning was an effective tool to enhance learning English grammar and vocabulary. The findings showed that students exposed to the blended learning method scores higher than those students exposed to conventional teaching methods, and the differences were statistically significant. The researcher also found out the student enrolled in blended learning are more excited and motivated to learn English than those who learn English in the traditional method. Based on the results of the study, several recommendations were presented. Teachers of EFL should consider using the blended learning strategy to teach all language skills (reading, listening, writing, and listening). Universities should hold workshops about blending learning to enable instructors to use blended learning methods in teaching. All universities are encouraged to implement blending learning in the curriculum. Besides, it is necessary to teach students how to use the e-learning 
system in their universities. Since the sample of the study is somehow small, the researcher recommends using a larger sample. Further research should be conducted to investigate the impact of blended learning on the development of different language skills, such as reading and speaking.

\section{Acknowledgement}

The researcher would like to thank both; the English instructors in the English department at Ajloun University College and the English students who participated in the study.

\section{References}

Adas, D. \& Bakir, A. (2013). Writing difficulties and new solutions: blended learning as an approach to improve writing abilities. International Human Journal of Humanities of Social Science, 3 (9), 242-249.

Al Bataineh, K. B, Banikalef, A. A. \& Albashtawi, A. H (2019). The Effect of Blended Learning on EFL Students' Grammar Performance and Attitudes: An Investigation of Moodle. Arab World English Journal (AWEJ) $10(1), 324-334$

Al-Essa (2018). The Impact of Using Edmodo as a Blended Learning Medium on Promoting Saudi EFL Female Secondary School Students' English Grammar. Al Imam Muhammad ibn Saud Islamic University, College of Languages and Translation, Department of English Language and Literature, KSA (Master Thesis). Retrieved from Arab World English Journal (ID Number: 221. November 2018, 1-112. DOI: https://dx.doi.org/10.24093/awej/th.221

Al-Jarf, Reima (2005). "The Effects of Online Grammar Instruction on Low Proficiency EFL Collage Students Achievement". Asian EFL Journal, 7 (4), 166-190.

Barra, Carmen (2005). Working with vocabulary. Chile. Retrieved from Internet http://www.teachingenglish.org.uk/think/vocabulary/working_with_vocabulary.shtml on July 11, 2019

Bataineh, R. F. \& Mayyas, M. B. (2017). "The utility of blended learning in EFL reading and grammar: A case for Moodle". Teaching English with Technology, 17(3), 35-49. Retrieved from http://www.tewtjournal.org

Fakhir, Z. (2015). The impact of blended learning on the achievement of the English language students and their attitudes towards it. Master thesis, Middle East University, Amman, Jordan.

Friesen M. (2012). Report: Defining Blended Learning. Available at: http://blogs.ubc.ca/ nfriesen/2012/09/01/where-does-blended-endvirtual-begin/ (accessed 17.06.2019).

Graham, C. R. (2006). Blended learning systems: Definition, current trends, and future directions. In Bonk, C. J., \& Graham, C. R. (Eds.), Handbook of blended learning: Global perspectives, local designs. San Francisco, CA: Pfeiffer.

Hrastinski, S. (2008). Asynchronous and synchronous E-learning. Educause Quarterly, 31 (4), 51-55.

Isti'anah, A. (2017). The effect of blended learning to the students' achievement in grammar class. Indonesian Journal of English Education, 4 (1), 16-30. http://dx.doi.org/10.15408/ijee.v4i1.5697

Khazaei, S., \& Dastjerdi, H.V. (2011). An Investigation into the Impact of Traditional vs. Blended Teaching on EFL Learners' Vocabulary Acquisition: M-learning in Focus. International Journal of Humanities and Social Science, 1(15), 202-207.

Krasnova T. A (2015). Paradigm Shift: Blended Learning Integration in Russian Higher Education. Procedia Social and Behavioral Sciences, 166, 399-403.

Marsh, D. (2012). Blended Learning: Creating Learning Opportunities for Language Learners. Cambridge: Cambridge University Press.

McCarthy, M. A., \& Murphy, E. A. (2010). Blended learning: Beyond initial uses to helping to solve real-world academic problems. Journal of College Education \& Learning, 7(6), 67-70.

Nation, Paul (2001). Learning vocabulary in another language. Cambridge: Cambridge University.

Olt, M. R. (2002). Ethics and distance education: strategies for minimizing academic dishonesty in online assessment. Online Journal of Distance Learning Administration, 5(3). Retrieved from http://www.westga.edu/ distance/ojdla/fall53/olt53.html.

Pazio, M. (2010). Blended learning and its potential in expanding vocabulary knowledge: A case study. Teaching English with Technology, 10(1), 3-30.

Procter C.T. (2003). Blended Learning in Practice. Available at: www.ece.salford.ac.uk/proceedings/ papers/cp_03.rtf

Qindah, S. (2018). The effects of blended learning on EFL students' usage of grammar in context. Eurasia Proceedings of Educational \& Social Sciences (EPESS), 5(10), 11-22.

Rovai, A.P, \& Jordan, H.P. (2004). Blended Learning and Sense of Community: A comparative analysis with traditional and fully online graduate courses. International Review of Research in Open and Distance Learning, 5 (2), 24-36.

Schechter, R., Macaruso, P., Kazakoff, E. R., \& Brooke, E. (2015). Exploration of a blended learning approach to reading instruction for low SES students in early elementary grades. Computers in the Schools, 32, 183-200. 
So, L., \& Lee, CH. (2013). A Case Study on the Effects of an L2 Writing Instructional Model for Blended Learning in Higher Education. Turkish Online Journal of Educational Technology, 12(4), 1-10.

Sucaromana, U. (2013). The Effect of Blended Learning on the Intrinsic Motivation of Thai EFL Students. English Language Teaching; 6 (5). P. 141-147.

Swan, K. (2002). Building learning communities in online courses: The importance of interaction. Education, Communication \& Information, 2(1), 23-49. http://dx.doi.org/10.1080/1463631022000005016.

Swan, M. (2008). Seven bad reasons for Teaching Grammar- and two good Reasons for Teaching Some. In Methodology in Language Teaching, ed. Richards and Renandya, CUP 2002.148-152.

Vasbieva, D.G., Klimova, I.I., Agibalova, E.L., Karzhanova, N.V., and Bírová, J. (2016). Enhancement of Students' Vocabulary Learning through a Blended Learning Approach. Look Academic Publishers - IEJME - MATHEMATICS EDUCATION, VOL. 11, NO. 5, 1195-1203. Retrieved on December 18, 2017, from iejme.com/makale/547

Walsh, S. (2016). The Role of Interaction in a Blended Learning Context. In McCarthy, M., ed., The Cambridge Guide to Blended Learning for Language Teaching. Cambridge: Cambridge University Press, pp. 36-52.

Wang, Y., Chung, C.J. \& Hattingh, E. (2014). A Blending Approach in Technology Integrated ESL Writing Instruction. In M. Searson \& M. Ochoa (Eds.), Proceedings of Society for Information Technology \& Teacher Education International Conference 1139-1144.

Zhang, H., Song, W., \& Burston, J. (2011). Reexamining the effectiveness of vocabulary learning via mobile phones. The Turkish Online Journal of Educational Technology, 10(3), 203-214.

Zumor, A. 1., Refaai, A. W., Bader I. K., Eddin, E. A. \& Al-Rahman, F. H. (2013) EFL students' perceptions of a blended learning environment: Advantages, limitations and suggestions for improvement. English Language Teaching, 6(10), 95-110. 